\title{
The Influence of Asmaul Husna Dhikr to Psychological Wellbeing of Employees
}

\author{
$1^{\text {st }}$ Evi Ni'matuzzakiyah \\ Sekolah Tinggi Ilmu Kesehatan Surya Global \\ Yogyakarta, Indonesia \\ bundaelsyamil@gmail.com
}

\begin{abstract}
The form of violence change based on age, workplace bullying is a serious problem that happen until now days, it includes physical bullying, verbal bullying, psychological bullying, and social bullying. Workplace bullying behaviors are pervasive in some healthcare organizations leading to difficult work environment. Then dhikr becomes one of the solutions of spiritual activity with the various problems that exist. This study is aimed at finding the influence of Asmaul Husna dhikr towards Psychological Wellbeing of the employees. This study involved 43 employees of the afternoon shift in Production division in PT Kharisma Export Yogyakarta as research subjects and intervention of Asmaul Husna dhikr. This study used quantitative research design and Psychological Wellbeing Scale as research instrument. The pretest and posttest data were then analyzed through the Wilcoxon test using SPSS 16. Based on $t$ Test, it showed that significance value was 0.001 , because value 0.001 was smaller than 0.05 , it could be concluded that "Ha was accepted" which meant that there was difference of psychological wellbeing of employees before and after Asmaul Husna dhikr. Thus, it could be concluded that "there was influence of Asmaul Husna dhikr on psychological wellbeing of employees."
\end{abstract}

Keywords-Asmaul Husna, dhikr, psychological wellbeing, employees

\section{INTRODUCTION}

Work is a fundamental aspect of life [10]. During last 25 years technological development has accelerated the globalization process which has caused dramatic changes within and cross organization. Business performance is varying, complex, global and is changing faster than ever before [12].

Work when organized and managed in certain ways, can produce various positive individual and societal benefits [10]. Wellbeing in the workplace has increasingly become a common topic in mainstream organizational research [22]. Kaplan et.al [10] show that employee wellbeing has a broader impact such as on the school performance of children of working parents.

In fact, the form of violence change based on age, workplace bullying is a serious problem that happen until nowadays, it includes physical bullying, verbal bullying, psychological bullying, and social bullying [9].

Workplace bullying behaviors are pervasive in some healthcare organizations leading to a difficult work environment [4].
Hidayati and Rahayuningsih [9] add that bullying is an aggressive behavior that happened on purpose to make physical discomfort or psychological discomfort to other, the position of worker that usually inferior has made factory workers become a potential object of workplace bullying.

The employees' turnover is basically influenced by many factors, including bullying at workplace and interpersonal conflict [18]. He adds that workplace bullying can be in the form of hiding information related to the jobs, the lack of freedom in telling employees' argument, the and the spread of gossip among the employees in the organization. It then creates interpersonal conflict which leads to employees' turnover. From his study, it showed that workplace bullying has a positive influence to the employees' turnover, and interpersonal conflict has a positive influence to employees' turnover [18].

It is realized that the unfriendly working climate creates someone to be bored and feeling worried. When it happens, many of them will look for spiritual activity as the solution, for instance, by performing dhikr. By all problems existed, dhikr presents as one way to accommodate the pressure mentioned above, therefore, one will get the balance between his or her thought and the real world. In addition, dhikr is also one of the mechanisms that can new energy (librari.walisongo.ac.id/digilib, 2017).

Then the new energy will eventually bring the individual to a psychological wellbeing, in which the individual is able to accept himself as the way he is, create a friendly relationship with others, possess independence in encountering social pressure, control external environment and possess goals in his life, and realize his potential over and over [6].

Psychological wellbeing is an individual's ability to optimize his psychological function featured by accepting his condition, developing his individual growth, building a positive relationship with others, having self-independence, having life goals, and controlling environment [14].

According to Ryff [6] Psychological wellbeing is an individual's ability to accept his own condition as what he is (self-acceptance), create relation with others (positive relation with others), have autonomy in encountering social pressure (autonomy), control external environment (environmental mastery), have life goals (purpose in life), and be able to realize his potential continually (personal growth). 
Psychological wellbeing is defined as a positive evaluation about someone's life associated by obtaining a pleasure feeling [17].

In the other hands, Hauser, Springer, and Pudrovska [8] explain that psychological wellbeing is also defined as an individual's psychological wellbeing focusing on selfrealization, personal expressiveness, and self-actualization.

Ryff \& Keyes [23] state that there is a difference of psychological wellbeing level based on age. The different age consists of three stages of adult development including younger, middle-aged adult, and later adulthood. The individuals in middle-aged adult can show higher psychological wellbeing than those in the younger and later adulthood stage related to some dimension of psychological wellbeing [16].

Based on the employees 'problems existed at the workplace mentioned previously, it is important to follow up in study field to reveal about the influence of Asmaul Husna dhikr to psychological wellbeing of the employees. However, the important roles of psychological wellbeing of individual's life at the workplace will influence his performance.

\section{MATERIALS AND METHOD}

\section{A. Objective Of Study}

This study is aimed at knowing the influence of Asmaul Husna dhikr towards psychological wellbeing of the employees and to provide alternative solutions in how making psychological wellbeing to the employees in a very basic way through Asmaul Husna dhikr.

In addition, it is expected that this study is able to provide contribution to the growth of psychological knowledge particularly in Occupational and Health Psychology.

\section{B. Research Time And Setting}

This study was conducted in PT Kharisma Export Yogyakarta. The research process was done in $14^{\text {th }}$ June 2017 to $8^{\text {th }}$ July 2017, started by getting research license from the director of PT Kharisma Export Yogyakarta which is located in Jalan Paris KM 3 Bantul Special District of Yogyakarta. Then in $15^{\text {th }}$ June 2017, the direction told the researcher about the certain time to conduct the research from $16^{\text {th }}$ June 2017 to $8^{\text {th }}$ July 2017. There were 43 employees of Production division that were getting permission as research subjects.

\section{Data Collecting Method}

Data collecting method is the researcher's method in obtaining data that are researched. It is purposed to reveal the fact about the variables researched [2].

The quality of the data is based on the quality of the instrument or the measurement. Thus, before the instrument was used, it was conducted try out of Psychological Wellbeing Scale through Google form.

The researcher then conducted validity and reliability test of the instrument. The validity test was conducted to know how far the scales use able to produce the accurate data in line with the purpose of measurement [3]. The instrument of measurement is called high valid when it runs as the function of measurement or provide the result of measurement which is appropriate with the purpose of conducting measurement [3].

The Psychological Wellbeing refers to the type of content validity and internal validity. Content validity is to show how far the items in the test include the overall scope of subject measured [3]. Content validity is to measure instrument by using rational analysis or by professional judgment that is how far the items included in the instrument appropriate with the attitude measured [3]. Meanwhile, internal validity is by using comparison criteria obtained from the instrument; by correlating the value of each item with total score [2].

The researcher then conducted reliability test which means as the constancy of measuring instrument to measure the same which means that when there are several times in measuring the same subject group, the results of those measurements are relatively the same; as long as the aspect of the subject measured has no change then the measurement can be reliable [3].

The high or low of measuring instrument is stated by the number called reliability coefficient. The value of reliability coefficient is in the range of 0.00 to 1.00 which means that the higher the reliability coefficient is obtained, the better reliability coefficient showed. Therefore, the reliability coefficient that is close to 1.00 means that there is a consistency of perfect measurement [3].

In this research, the reliability coefficient of Psychological wellbeing scales used Alpha Cronbach correlation in SPSS 16.0 for Windows.

Reliability test for Psychological wellbeing scale used item validity by the help of SPSS 16.0 for Windows by correlating each value of each item with total score. Based on the test, it was obtained 37 items from 45 items as valid.

The next research procedure was collecting data started by taking administration procedure that is asking for getting research license to PT Kharisma Export Yogyakarta. The researcher conducted observation and interview with production division.

Before performing an intervention, the employees were asked to fill Psychological Wellbeing scale assisted by the researcher. Then, it was performed intervention as Asmaul Husna dhikr led by spiritual company (ustadz).

Asmaul Husna dhikr is defined as the best names of Allah SWT [20].

At the time of intervention, each employee was given guide book of Asmaul Husna dhikr written by KH. Amdjad al Hafidz. The dhikr was performed together led by ustadz. After getting intervention for two weeks, the employees were asked to fill psychological wellbeing scale once more to be measured the wellbeing level after performing Asmaul Husna dhikr.

\section{Data Analyzing Method}

The research subjects were the employees of PT Kharisma Export Yogyakarta, and most of them were living in Bantul area with the age range was between 22 to 47 years old.

On $16^{\text {th }}$ June 2017 at $06.30 \mathrm{pm}$, the employees of Production division in the afternoon shift were firstly given 
briefing related to the research conducted. They were asked to fill Psychological Well Being scale as pretest before performing Asmaul Husna dhikr.

On the next day, on $17^{\text {th }}$ June 2017 to $8^{\text {th }}$ July 2017, at $06.30 \mathrm{pm}$ it was done Asmaul Husna dhikr headed by Spiritual Company (Ustadz) routinely for 30 minutes (until 07.00pm).

On $8^{\text {th }}$ July 2017, the employees of Production division in afternoon shift were asked to fill Psychological Well Being for the second time as posttest.

Based on the result of pretest and posttest, the normality test showed that the distribution was not normal. Therefore, the researcher process the final data by using non-parametric statistical test Wilcoxon Signed-Rank Test, when the samples are dependent, as they would be in a before-and-after test using the same subject, the Wilcoxon signed-rank test can be used in place of the $t$ test for dependent samples. Again, test does not require the condition of normality [5] by using SPSS 16.0 program for Windows.

\section{RESULT AND DISCUSSION}

The research conducted was purposed to obtain the real data. The data were then analyzed statistically to test research hypothesis. The first procedure, it was conducted normality test for pretest data. Since the data was not in normal distribution, the researcher then used Wilcoxon test to find out the difference before and after Asmaul Husna dhikr intervention. The result of Wilcoxon test can be seen in the following table.

TABLE 1: RESULT OF PRETEST ANDPOSTTEST OF THE EMPLOYEES BY USING WILCOXON TEST

\begin{tabular}{|c|c|c|c|}
\hline Score Data & $\mathrm{N}$ & Means & Sum \\
\hline $\begin{array}{c}\text { Pretest (in } \\
\text { positive score) }\end{array}$ & 16 & 9.22 & 147.50 \\
\hline $\begin{array}{c}\text { Posttest (in } \\
\text { negative score) }\end{array}$ & 1 & 5.50 & 5.50 \\
\hline $\begin{array}{c}\text { Similarity of } \\
\text { Pretest and } \\
\text { Posttest }\end{array}$ & 26 & & \\
\hline Sum & 43 & & \\
\hline
\end{tabular}

Based on the table of statistics result through Wilcoxon test by using SPSS 16, the Negative Ranks between the result of pretest and posttest of the employees' psychological wellbeing before and after Asmaul Husna dhikr was 1 in the N value 5.50 for Mean Ranks and Sum Ranks. The value 1 showed that there was improvement from the score of Pretest to Posttest.

Positive Ranks between the result of pretest and posttest of the employees' psychological wellbeing scale after Asmaul Husna dhikr showed 16 positive data (N) from 43. It meant that there were 16 employees who got improvement of psychological wellbeing from the result of pretest to posttest. Mean Ranks was 9.22, while positive ranks or Sum Ranks was 147.50.

In addition, Ties was the similarity of the score of Pretest and Posttest. The Ties was 26 which could be concluded that there were the similar scores between those in Pretest and Posttest as many as 26 employees.

It was then conducted t test from the data of pretest and posttest. The result of $t$ test can be seen in the following table.

TABLE 2. RESULT OF T TEST

\begin{tabular}{|c|c|}
\hline T test & $\begin{array}{c}\text { Pre test } \\
\text { Post test }\end{array}$ \\
\hline Z Value & $-3.443^{\mathrm{a}}$ \\
\hline Significance Value & 0.001 \\
\hline
\end{tabular}

Based on the statistical test output above, it was known Asymp.Sig. (2-tailed) was 0,001. Because the value 0,001 was smaller than 0,05 , it could be concluded that "Ha was accepted". It meant that there was difference before and after performing Asmaul Husna dhikr.

The similar research about wellbeing was done by Maulidina and Nurtjahjanti [14] who found that there was significant negative relationship between discomforts at workplace toward psychological wellbeing of the outsourcing employees in Sultan Agung Hospital, Semarang.

Khasanah [11] conducted experimental research with Asmaul Husna dhikr intervention to children in orphanage Darussalam, Mrenggan, Demak. She found that there was difference of anxiety level in the National Exam before and after getting Asmaul Husna dhikr intervention.

In addition, Latief and Ratnaningsih [13] stated their research finding that there was a positive relationship between Leader Member Exchange and psychological wellbeing of inpatient ward nurses in RSUD Cideres Majalengka.

Still about employees' wellbeing, Simarmata [21] explained two findings. First,result of correlation analysis showed that there was a positive relationship between job satisfaction and employee wellbeing. Second, the job satisfaction and wellbeing of the employees were average.

Aruan and Fakhri [1] found in their research that the physical work environment and the non-physical work environment had the most positive and significant influence to the employees satisfaction.

Nugraheni [15] showed that in her research finding, there is a significant positive relationship between psychological wellbeing and social support on an honorary teacher area.

Sari [19] showed that there is a significant negative relationship between psychological wellbeing with a dual role conflict. 
Wardani and Sawitri [25] found that there was a positive and significant relationship between career calling and psychological wellbeing of the staff in the jail.

Tanujaya [24] found that there was rather lower positive relationship between working satisfaction and psychological wellbeing.

According to Edward and Richard [7] they stated that Self Determination theory (SDT) has been applied in varied culture and in many domains, and research is reviewed that has related autonomous and controlled motivation to education, parenting, work, health care, sport, and close relationship.

One limitation of this study was a small sample size. Although researcher achieved adequate power for the quantitative analyses, the findings are not representative of how all employees would feel and get wellbeing by dhikr intervention. The limitation time of intervention also had impact in the result of this research. In this study, researcher also depended on self-reports of the subjects of study, potentially creating response bias.

\section{CONCLUSION}

There is no employee who does not have problem at workplace. By all problems existed, it demands an employee to find the best solution, one of them is by performing a positive spiritual activity that is Asmaul Husna dhikr. Dhikr presents as one way to accommodate the pressure mentioned above, therefore one will get the balance between the thought and the real world. In addition, dhikr is also one of the mechanisms that can add new energy. Then, the new energy will eventually bring the individual to a psychological wellbeing level. It then leads an individual to have selfacceptance, autonomy in encountering social pressure, external environment mastery, purpose in life and be able to realize his own potential continually.

\section{ACKNOWLEDGMENT}

STIKES Surya Global Yogyakarta funded this study via Lembaga Penelitian dan Pengabdian Masyarakat.

\section{REFERENCES}

[1] Aruan, QS \& Fakhri, M 2015, The influence of work environment on job satisfaction of Grasberg Power Distribution field employees of PT Freeport Indonesi, Jurnal Modus, vol.27 (2): 141-162.

[2] Azwar, S 2010, 'Research methods, Yogyakarta: Pustaka Pelajar.

[3] Azwar, S 2011, 'Validity and reliability', Yogyakarta: Pustaka Pelajar.

[4] Berry, PA, Gillespie, L, Fisher, BS, Gormley, D, Haynes, JT, 2016, 'Psychological distress and workplace bullying among registered nurses', OJIN: The online journal of Issues in Nursing, Vol. 21, No.3, downloaded in 24 April 2018.

[5] Bluman, AG 2012, 'Elementary statistic a step by step approach', Eighth Edition.New York: McGraw-Hill.

[6] Carr, A 2004, 'Positive Psychology, The Science of Happiness and Human Strength', New York: Brunner-Routledge.

[7] Edward LD \& Richard MR 2008, 'Facilitating optimal motivation and psychological wellbeing across life's domains', Canadian Psychology, Vol.49 No.1, 14-23, doi: 10.1037/0708-5591.49.1.14,
https://selfdeterminationtheory.org/SDT/document/2008_DeciRyan CanPsy_Eng.pdf, downloaded in 21 April 2018.

[8] Hauser, RM, Springer, KW, Pudrovska, T 2005, 'Temporal Structures of Psychological Well-Being: Continuity or Change?', Paper of presentation at the 2005 annual meetings of the Gerontological Society of America, Orlando, FL https://www.ssc.wisc.edu/ hauser/HSP Temporal\%20Structures\%20of \%20PWB GSA2005 111405a.pdf, downloaded in 1 March 2017.

[9] Hidayati, N \& Rahayuningsih, I 2014, 'The form and impact of workplace bullying on factory workers in Gresik ', Journal of Psychoscience, vol.9, No.2, journal.umg.ac.id/index.php/psikosains/article/download/244/197/, downloaded in 23 April 2018.

[10] Kaplan, S, DeShan, RP \& Tetrick, LE 2017, 'The bigger picture of employee wellbeing: Its Role for individuals, families, and societies. Society for human resource management and society for industrial and organizational psychology, https://www.shrm.org/hr-today/trends-andforecasting/special-reports-and-expertviews/document/2017\%2002 SHRM-SIOP\%20Employee\%20Wellbeing.pdf, downloaded in 23 April 2018.

[11] Khasanah, I 2015, 'The influence of doing Asmaul Husna dhikr to the anxiety in facing the National Examination of the children of Darussalam maids Mrengga Demak ' Skripsi, Universitas Islam Negeri Walisongo Semarang. Eprints.walisongo.ac.id/4807/1/111111066.pdf,downloaded in 21 April 2018.

[12] Krainz, KD 2015, 'Enhancing wellbeing of employess through corporate social responsibility context', Original Scientific Paper, vol. 12, No. 2:137-154. Scindeks-clanci.ceon.rs/data/pdf/1820-3159/2015/182031591502137D.pdf, downloaded in 23 April 2018.

[13] Latief, PM \& Ratnaningsih, IZ 2016, 'Leader member exchange (LMX) dan kesejahteraan psikologis pada perawat rawat inap di RSUD Cideres Majalengka', Jurnal Empati, vol.5 (1), 127132.https://media.neliti.com/media/publications/66471-ID-leadermember-exchange-Imx-dan-kesejahte.pdf, downloaded in 21 April 2018.

[14] Maulidina, NR \& Nurtjahjanti, H 2016,. 'Relationship between work discomfort with psychological well being on contract employee Sultan Agung Islamic Hospital' Journal of Empathy, vol. 5 (2), 189-194, https://media.neliti.com/media/publications/70885-ID-hubungan-antaraketidakamanan-kerja-deng.pdf, downloaded in 21 April 2018.

[15] Nugraheni, S 2016, 'The relationship between social support and psychological well being in local teachers' honorarium, Publication Script, Faculty of Psychology Universitas Muhammadiyah Surakarta, Eprints.ums.ac.id/44171/19/Naskah\%2020Publikasi-agi.pdf. downloaded in 21 April 2018.

[16] Papalia, DE, Stern, LH, Feldman, RD \& Camp, CJ. 2002, 'Adult Development and Aging ( $2^{\text {nd }}$ Ed). New York: McGraw Hill, Inc.

[17] Pinquart, M \& Sorensen, S 2000, "Influences of Socioeconomic Status, Social Network, and Competence on Subjective Well-Being in Later Life: A Meta-Analysis', Psychology and Aging, 15(2), 187-224. https://www.researchgate.net/profile/Silvia Soerensen/publication/1243 8552_Influences_of_Socioeconomic_Status_Social_Network_and_Com petence on Subjective Well-Being in Later_Life_A MetaAnalysis/links/02bfe50fedd19b38f0000000/Influences-ofSocioeconomic-Status-Social-Network-and-Competence-on-SubjectiveWell-Being-in-Later-Life-A-Meta-Analysis.pdf, downloaded in 1 April 2017

[18] Prasetyo, FDM 2017, 'The effect of workplace bullying and interpersonal conflict at work on employee turnover at PT Suri Tani Pemuka Lampung', Digilib.inila.ac.id/28592/3/SKRIPSI\%20TANPA\%20BAB\%20PEMBA HASAN.pdf, downloaded in 23 April 2018.

[19] Sari, NK 2016, 'Psychological wellbeing relationship with dual role conflict on employee working in Kaltim bank of Samarinda city', Ejurnal.untagsmd.ac.id/index.php/MTV/article/view/2477, downloaded in 21 April 2018.

[20] Shihab, Q 2000, 'Tafsir Al-Azhar Juz XXVIII', Jakarta: Pustaka Panji Mas. 
[21] Simarmata, NI 2015, 'The effect of job satisfaction on well being employees at PT. Intan Hevea Industri Medan ', Journal of Psychology Universitas HKBP Nommensen. ISSN 2460-7835, vol.1, No.1, https://perpustakaan.uhn.ac.is/adminarea/dataskripsi/Nenny\%201.pdf, downloaded in 21 April 2018

[22] Simone, SD 2014, 'Conceptualizing wellbeing in the workplace', International journal of business and social science, vol.5, No. 12.https://ijbssnet.com/journal/vol_5_no_12_november_2014/14.pdf, downloaded in 21 April 2018.

[23] Snyder, CR \& Lopez, SJ, Eds 2002, 'The Handbook of Positive Psychology', New York: Oxford University Press.
[24] Tanujaya, W 2014, 'Relationship of job satisfaction with psychological wellbeing on cleaner employees (study on cleaner employees receiving salary not in accordance with UMP standard in PT Sinergi Inegra Services Jakarta), Journal of Psychology, vol. 12, no.2, https://media.neliti.com/media/publications/126322-ID-hubungankepuasan-kerja-dengan-kesejahte.pdf, downloaded in 21 April 2018.

[25] Wardani, AA \& Sawitri, DR 2015, 'Career calling dan psychological wellbeing pada petugas di Lembaga Pemasyarakatan Klas 1 Semarang', Jurnal Empati, 